\title{
The impact of access to credit on process innovation
}

\author{
Abdul Wahab Aidoo \\ International University of Sarajevo, Bosnia
}

*Corresponding author: awaidoo@gmail.com, aaidoo@student.ius.edu.ba

(C) The Author

2020.

Published by

ARDA.

\begin{tabular}{ll} 
Abbreviations & \multicolumn{1}{c}{ Sub-Saharan Africa } \\
AFR & East Asia and the Pacific \\
EAP & Europe and Central Asia \\
ECA & Latin America and the Caribbean \\
LAC & Mean Percentage Error \\
MPE & Middle East and North Africa \\
MNA & Organization for Economic Co-operation and Development \\
OECD & Ordinary Least Square \\
OLS & Research and Development \\
R\&D & Root Mean Square Error \\
RMSE & South Asia Region \\
SAR & Small and Medium Scale Enterprises \\
SMEs & World Bank Enterprise Survey \\
WBES &
\end{tabular}

\begin{abstract} The effectiveness of a firm mostly depends on the capability of the managers to obtain flexible credits for the implementation of sustainable innovations. The aim of this study is focused on the impact of access to credit on process innovations in SMEs. Data from the manufacturing and the service sectors of the economies of Africa and the Middle East are collected from the World Bank's Enterprise Survey database. The survey employs random sampling to select firms in each country and they are stratified based on the number of employees. The sampled observations are scaled down from 136,887 to 33,977 firms covering 53 countries due to the scope of this research. The factors of access to credit are the independent variables of this research: the working capital from a commercial bank, overdraft facility, lines of credit, external auditing of accounts, and working capital from suppliers. The dependent variable is process innovation. The results show that there are significance levels of p-values below $1 \%$ although some of the Pearson correlation coefficients of the independent variables with the dependent variable are not too high. The factors of access to credit used in the regression model have a significant impact on process innovation. The findings from the analysis help the policy directions of managers.

Keywords: Innovation; Process Inmovation; Financial Credit; Small and Medium

Keywords: Innovation; Process Innovation; Financial Credit; Small and Medium

Scale Enterprises
\end{abstract}




\section{Introduction}

The innovative activity provides fundamental support for firms to accelerate their growth and development. The insight of this research study is geared towards the impact of credit accessibility of a firm on its business activities relating to innovation. In this research study, indicators of access to credit of a firm comprise of: working capital from a commercial bank, working capital from suppliers, overdraft facility, lines of credit, and external auditing of accounts. This research study is focused on small and medium scale enterprises (SMEs). Innovation is regarded as the fundamental tool in every organization to create and spearhead the growth potential of the organization and the country as a whole [1], [2], [3] [4]. According to Miller (1983) for entrepreneurship to be sustainable in a competitive industry, there should be a strong feature of risk-taking and radical innovation. Therefore, it has become important to commence the concept of innovation implementation at the SMEs level so as to ensure long-run survival and development in the competitive market [5], [6], [7], [8], [9].

Research studies investigated in the field of management innovation have shown the extent to which innovative activities of firms can impact on business operation. The review of innovation literature through the activities of credit accessibility and financial institutions in SMEs in developing countries is inadequate [10]. The objective of this research study is to contribute to reduce the gap in the academic literature by finding out how the innovation in SMEs are influenced by the types of accessibility to credit (finance) in the two geographical regions of Africa and the Middle East.

\section{Literature review}

The ability to access finance and commence any profitable investment opportunities is an essential feature for the success and sustainability of any firm and organization [11], [12]. The success of individual firms will ultimately harness the economic growth and development of the society and the country at large [13]. Challenges such as inadequate liquidity are bound to hamper the ability of both prospective entrepreneurs from commencing their firms, and new entrepreneurs from enhancing the progress of their firms [14], [15]. The study by Klapper, Laeven, and Rajan (2006) in 35 European countries reveals that for countries with a robust financial development, it is difficult for financially dependent firms to enter into their market. To make it easy for new and young firms to enter into a market and ensure their sustainability, the financial arrangements in the financial sector need to be comfortable [16].

The pecking order theory of financing is used to explain the financing options available to matured as well as already established firms [17]. The matured firms generally, have adequate funds available from their internal resources. This is due to the high-profit potential and less growth in the market. In this case, firms will prefer to make use of internally accumulated funds first, before sourcing for external funds [18], [19]. Firms with a good and credible financial status such as a sustainably good history of credit, reduce the challenges of trust and high transactional costs between them and their creditors. Comparatively, mature firms are able to secure adequate credits and finances on flexible financial conditions than new and young firms which have not been able to demonstrate enough record on the fulfillment of their financial obligations in the financial market [18], [20], [21]. For instance, new firms and entrepreneurs are able to commence business and survive in the competitive financial market when there is a healthy relationship between the financial institutions and them [22], [23], [24], [25].

Start-up and young firms with inadequate access to formal financial institutions might turn their attention to the available informal sources to seek credit and support. The informal sources of credit available to firms include; suppliers, family, and friends. These available sources of credit become a comfortable resort for young firms to achieve their relevance in the market and grow sustainably [26]. Although informal sources of credit are easily available for firms, they pose some challenges to them. Transactions in the informal sector are unregulated which makes the cost of credit relatively expensive. Again, it is not imperative for firms to rely on 
the funds from informal sources because they cannot be accessed on time. For instance, in an environment where formal officials are perceived to be taking and accepting gifts from individuals before they conduct an official duty, firms prefer to use informal sources to obtain credit to run their business than going through the formal financing path [27], [28]. Firms are willing and ready to incur the high cost of accessing credit in the informal sector in order to avoid the likelihood of giving gifts and favors to officials [29].

\subsection{Access to credit}

For a firm to have the potential to embark on innovation, the financial structure and sources of working capital of the firm should be on a sound footing. Firms should have diverse sources and flexible price of credit to support the innovativeness of the firm. This will help to enhance the firms' growth and development. The financial structure and types of credit for firms considered under this study are: working capital from banks, working capital from suppliers, overdraft facility, lines of credit, and external auditing of accounts.

\subsubsection{Working capital from banks}

With regards to the relation between level of financial enhancement and innovation, the research by Schumpeter in 1912 highlighted the discussion of credit and funding to support the innovation of firms. Schumpeter's "Economic Development Theory" indicates the development of financial credit, interest and other monetary variables [30].

Studies in financial development have shown an appreciable relationship between a sound financial growth and development and innovation of firms. Well-developed financial institutions in a country are indication of economic growth. With a robust financial environment, commercial banks become a hub for firms to access credits and capital accumulation with less difficulty, which supports them to improve their investment, growth and innovativeness [13], [31].

Inadequate developments in financial institutions go a long way to hamper the growth and development of firms that obtain majority of their capital accumulation from external sources or commercial banks [32]. In a similar vein, credit accessibility from commercial banks comes with much challenge in countries that have unregulated property rights system [15]. The information asymmetries in the financial sector, possess more difficulty to firms to accumulate working capital from banks, and this has been corroborated by the studies of Chirinko and Schaller (1995); Schaller (1993); and Hoshi, Kashyap and Scharfstein (1991). However, information asymmetry is reduced to a large extent when firms develop a close relationship with formal financial institutions [33], [34], [35].

\subsubsection{Overdraft facility}

Overdraft facility is a very popular financial instrument in the environment of commercial banking. It is used as an emergency capital accessibility given by the commercial banks to their reliable and trusted customers who are in need of liquidity to service and/or finance their maturing obligations. State enterprises and agencies make use of these available services in the banking sector just as their competitors in the private sector. For instance, in India, the gap in the financial space created as a result of firms' overdraft is helped and filled by the Reserve Bank of India [36].

The diverse channels by which SMEs can use to access credit for their innovation, growth and development are still in the state of evolving [10]. One of the channels through which SMEs can employ to facilitate their access and accumulate working capital is by an external financial facility. Although investigations by historians such as Landes (1969); Rosenberg (1982); and Mokyr (1990) reveal that improvement in technological and administrative innovations are the major factors for the development of firms over a long period, additionally, Solow (1957) argues for the inclusion of capital as one of the factors [37], [38], [39], 
[40]. For instance, between the periods 1909-1949 in the United States, $80 \%$ of the increase in labor productivity was as a consequence of the availability of working capital from banks and skilled labor [40].

\subsubsection{Lines of credit}

Firms give their customers the opportunity to delay their payment of goods and services already delivered. This is done by offering customers some flexible terms of trade credit to assist the firms to deal with problems that result from liquidity. Results from prior studies have identified the importance of trade credits to SMEs businesses. External credits are offered to firms in the form of short-term finances [41], [42].

Reports from various studies have identified empirical evidence that points to the existence of a relationship between lines of credits available and the growth rate of firms [43]. In situations where firms encounter liquidity challenges which have the potential to adversely affect the innovation and growth rate, they resort to relative sources of credit to sustain their business activities and hence the development [44]. The need to seek sources of external finance for business activities is a characteristic of fast-growing firms. It is reported that relatively fast-growing firms form the habit of not settling their payment of credit on time because they have other sources of credit to rely on. Again, firms which possess more intangible assets have the propensity to indulge in several sources of credit than those with less intangible assets [45], [43].

As suggested with empirical evidence from previous studies, the demand for credit has a direct relationship with credit constraints [46]. Firms especially, SMEs that have available resources to embark on innovation activity tend to use lines of credit. SMEs that have more of their assets in the intangible form are in a higher position to meet the criteria required by commercial banks for financial support [47], [48]. SMEs with innovation activities in their businesses are expected to engage in several lines of credit to boost their working capital. This is because comparing large firms to SMEs make them not susceptible to the constraints and challenges of credit accessibility due to their capacity and sheer experience in the financial market [49], [50], [51], [41].

\subsubsection{Working capital from suppliers}

Firms seek the services of their suppliers, in the short-run, to access flexible working capital or credit. The credit acquired from the suppliers has a less price attached to them with more elastic demand. Firms that are facing financial difficulties are able to obtain some credit relieves from their suppliers. Suppliers have a longrun motivation to assist their customers who have been indulged in financial difficulties so as to keep their business activities in progress [52], [53]. There is no formal procedure and documentation when firms are transacting with their suppliers. The terms of a transaction are also negotiable in a win-win situation. This reduces stress and increases the easiness in their transaction process. Innovative SMEs do tap into the credit resources available from their suppliers in situations of financial challenges or when access from commercial banks becomes impossible [41].

According to Schwartz (1974) suppliers provide more credit options and benefits to firms than the financial support obtained from formal financial institutions and commercial banks [54]. There are three major channels to obtain these benefits, they are:

1) Controlling of buyers;

2) Acquisition of information; and

3) Retrieving values from already existing assets.

Due to a cordial relationship that exists between firms and their suppliers, and obtaining information on firms by their suppliers become easy and cheap. Suppliers employ diverse channels to obtain information about firms and customers they transact with. However, relatively commercial banks do not have enough sources to obtain information about firms they deal with. This makes suppliers supply their goods to and retrieve 
delivered goods from firms if the firms fail to fulfill their agreed payment schedule. The retrieval of the goods can be done quickly before the firms integrate them into intermediate or finished products [53]. On the other hand, formal financial institutions and commercial banks do not have such privileges, power and speed to salvage the goods from their customers and firms [55].

\subsubsection{External auditing of accounts}

The pricing decision of creditors is highly sensitive to the account statement variables that are usually to analyze the credit feasibility of the firm when the account has been certified by an auditor. The measure of credit feasibility includes: the tangibility of assets, current ratio, coverage of interest, and to mention a few. The auditing of account statement is an addition of value to creditors and that an audited statement is not considered as a mere signal of cost. The influence of an audited financial statement has a significant influence on the decision of creditors of a loan. This implies that an audited financial statement supports the ability of firms to generate enough cash flow than the unaudited financial statement. The cash flow is used as sufficient working capital to enhance business transaction and undertake innovation activities [56], [57], [58].

Creditors use the information on audited accounts more thoroughly to enable them to settle on a feasible interest rate. Unfortunately, firms with an unaudited account miss out of this benefit. In SMEs, the interest rate payable on loans and credits from commercial banks is reduced to a sufficient level when the account statement submitted for credit accessibility has been audited by a certified accounting firm. A lower interest rate reduces the burden of repayment of credits on firms. Firms will have enough capital space to expand their business and engage in innovation [56].

\subsection{Firm age and size}

The age and size of a firm are considered as the control variables in this study. The age of a firm is regarded as the number of days, months or years it firm has been operating in the market. The size of a firm is considered as the number of formal and permanent workers in the firm. In this study, the firm size is defined as the number of permanent workers from one to ninety-nine (1-99).

\subsection{Process innovation}

Process innovation of a firm is described as the establishment of new or significantly improved methods of delivering goods and services [59], [60]. For instances, a significant change in the working methods, human resources, equipment/software or a combination of these. Process innovation can decrease the unit cost of production which in turn increases the quality of products and services [61]. The process innovation has favorable features and they are: the size of a firm, competition, and upstream knowledge [62]. Process innovation enhances the revolution of processes in the firms' day-to-day activities. They bring efficiency in the transformation of production and business processes in the firm. This impacts directly on the growth, development and hence the profit margin of firms [63]. According to Fagerberg et al. (2004) the benefits accrued from process innovation on the growth and development of firms are clear and easily noticed [64].

In view of the on-going discussions, the following hypotheses are proposed by this research:

- Hypothesis 1: Access to credit has a significant impact on SMEs' process innovation.

H1a: The impact of working capital from commercial bank on SMEs' process innovation is significant.

H1b: The impact of overdraft facility on SMEs' process innovation is significant.

H1c: The impact of lines of credit on SMEs' process innovation is significant.

H1d: The impact of external auditors on SMEs' process innovation is significant. 
H1e: The impact of working capital from suppliers on SMEs' process innovation is significant.

The Figure 1 below shows a summary of the theoretical framework and hypotheses of the research.

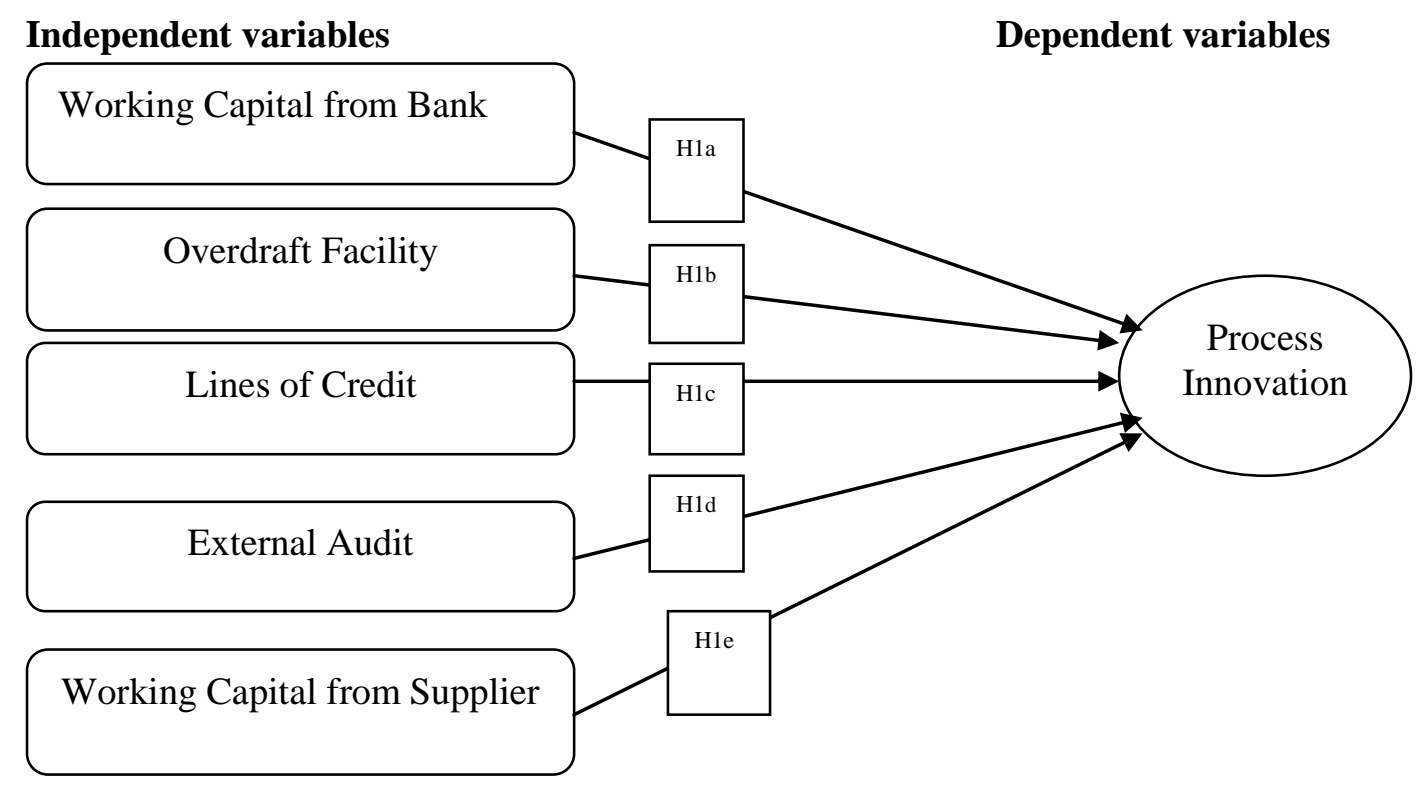

Figure 1: Theoretical Framework and Hypotheses

\section{Research method}

Variables and data to construct models and analyses in this research are explained in this section. Industrylevel data are taken from the database of the World Bank Enterprise Survey (WBES) [65]. The questionnaires are administered in the year 2006 through to the year 2018. The questionnaires are conducted in countries that are considered as emerging and/or developing nations. The questionnaires are directed to firms that are categorized as small-scale enterprises, thus, firms with full-time/permanent employees between 1 and 99. A random sampling method is used to select firms that are engaged in manufacturing and services in the market. The use of this database by renowned management innovation investigators such as Yang (2016); and LiPuma, Newbert and Doh (2013) shows the reliability and validity of the data [66], [67].

From the data, a total of 136,887 firms are observed in 138 countries from the manufacturing and servicing sectors in the economies of Sub-Saharan Africa (AFR), East Asia and the Pacific (EAP), Europe and Central Asia (ECA), Latin America and the Caribbean (LAC), the Middle East and North Africa (MNA), and South Asia region (SAR).

The study is skewed to two geographical regions (i.e., AFR and MNA), which reduces the total observation from 136,887 to 41,336 firms in 53 countries. Any firm with a total number of permanent workers above 100 is removed from the data. The age of each firm is also kept. The youngest firm is one year old and the oldest firm is 212 years old. Overall, a total of 33,977 firms are remained as the sample for the research analyses and discussions.

Diverse factors of access to credit and innovation are indicated in the WBES innovation database. These factors are classified into two disjoint categories. The factors in the first category are considered as access to credit that influences innovation in SMEs, which are named as independent variables: capital from bank, overdraft facility, lines of credit, capital from supplier, and external auditing of accounts. The second category is a factor that is considered as innovation in SMEs, and is named as dependent variable (i.e., process 
innovation). To determine the statistical significances of all the factors, a Pairwise correlation analyses are conducted between the independent variables and the dependent variable. The dependent variable is dummy, where Yes $=1$, and $\mathrm{No}=0$.

\subsection{Attributes}

This section shows the various attributes that are used for this research study. The attributes are taken from diverse innovation literature and management innovation guidelines prepared by the OECD. The type of attributes with the supporting innovation literature for both the independent variables and the dependent variable are shown below:

Working Capital from Commercial Bank. This independent variable is based on the research studies of Levine, (2005); Levine, Loayza and Beck (2000); and Demirguc-Kunt and Maksimovic (1998). The questionnaire asks respondents to indicate in percentage (\%) of the extent to which they are able to access credit from commercial banks relative to credits they receive from all sources.

Overdraft Facility. The use of this indicator as an independent variable is based on the research work of Thavaraj (1982). The survey asks respondents to indicate on a dummy scale (Yes=1, No=0) whether they are able to access credit through an overdraft facility.

Lines of Credit. The use of this factor as an independent variable is based on the studies of Bonte and Nielen (2011); Ng, Smith, and Smith (1999); and Tsuruta (2008). The survey asks respondents to indicate on a dummy scale ( $\mathrm{Yes}=1, \mathrm{No}=0$ ) whether their lines of credit enables them to access credit.

External Audit. The use of this factor as an independent variable is based on the research of Minnis (2011). The survey asks respondents to indicate on a dummy scale ( $\mathrm{Yes}=1, \mathrm{No}=0)$ whether they engage the services of an external auditor to verify their account statement.

Working Capital from Suppliers. This independent variable is based on the research studies of Pike, Cheng, Carvens, and Lamminmaki (2005); and Petersen and Rajan (1997). The questionnaire asks respondents to indicate in percentage $(\%)$ of the extent to which they are able to access credit from the suppliers of the firm relative to credits the firm receives from all sources.

Process Innovation. The selected variables are guided by previous studies (OECD Oslo Manual, 2005; Gunday, Ulusoy, Kilic \& Alpkan, 2011; Tidd, Bessant, \& Pavitt, 2005). Respondents are asked to indicate the value of variables on a dummy scale $(\mathrm{Yes}=1, \mathrm{No}=0)$ whether their firms have in the last three years engaged in process innovation. The "last three years" is used in the questionnaire to enable investigators to detect how firms are abreast with the changing demands in the competitive market.

The

Table 1 below shows a summary of the attributes for all independent and dependent variables.

Table 1. Variables, attributes, and references

\begin{tabular}{|l|l|l|}
\hline \multicolumn{1}{|c|}{ Variables } & \multicolumn{1}{|c|}{ Attributes } & \multicolumn{1}{c|}{ References } \\
\hline Capital from Bank & $\begin{array}{l}\text { Credit from commercial } \\
\text { bank }\end{array}$ & $\begin{array}{l}\text { Levine (2005); Levine, Loayza \& Beck } \\
\text { (2000); Beck, Demirguc-Kunt \& } \\
\text { Maksimovic (1998) }\end{array}$ \\
\hline Overdraft Facility & Credit by overdraft & Thavaraj (1982) \\
\hline Lines of Credit & Finance from lines of credit & $\begin{array}{l}\text { Bonte \& Nielen (2011), Ng, Smith \& } \\
\text { Smith (1999); Tsuruta (2008) }\end{array}$ \\
\hline External Audit & $\begin{array}{l}\text { Services from external } \\
\text { auditors }\end{array}$ & Minnis (2011) \\
\hline
\end{tabular}




\begin{tabular}{|l|l|l|} 
Working Capital from Supplier & Credit from supplier & $\begin{array}{l}\text { Pike, Cheng, Carvens \& Lamminmaki } \\
\text { (2005); Petersen \& Rajan (1997) }\end{array}$ \\
\hline Innovation & Process Innovation & $\begin{array}{l}\text { OECD Oslo Manual (2005); Gunday, } \\
\text { Ulusoy, Kilic \& Alpkan (2011); Tidd, } \\
\text { Bessant \& Pavitt (2005) }\end{array}$ \\
\hline
\end{tabular}

\subsection{Data analyses}

The data analyses of this research are described in this subsection. The descriptive statistics: mean, standard deviation, minimum, and maximum of all the independent and the dependent variables are given. Again, the analyses and discussions of the Pairwise correlations of all independent and dependent variables are shown. These are followed by discussions of the regression model, analyses and outcomes. The Table 2 indicates the descriptive statistics of the independent and the dependent variables.

Table 2. Descriptive statistics of dependent and independent variables

\begin{tabular}{lccccc}
\hline \multicolumn{1}{c}{ Variables } & Observations & Mean & $\begin{array}{c}\text { Standard } \\
\text { Deviation }\end{array}$ & Minimum & Maximum \\
\hline Process Innovation & 19800 & 0.414 & 0.493 & 0 & 1 \\
Capital from Bank & 32031 & 6.395 & 17.773 & 0 & 100 \\
Overdraft Facility & 31675 & 0.254 & 0.435 & 0 & 1 \\
Lines of Credit & 33059 & 0.172 & 0.378 & 0 & 1 \\
External Audit & 33494 & 0.474 & 0.499 & 0 & 1 \\
Capital from Supplier & 32728 & 11.498 & 20.049 & 0 & 100 \\
Age & 24077 & 16.386 & 13.837 & 1 & 212 \\
Size & 33977 & 18.63 & 18.808 & 1 & 99 \\
\hline
\end{tabular}

\subsubsection{Pairwise correlations between independent variables in access to credit and process innovation}

The results of the Pairwise correlations between all the independent and dependent variables are shown in this subsection. The findings reveal the relationships and the correlation coefficients that exist between all the independent variables, control variables, and the dependent variables.

From Table 3 the results reveal a positive correlation coefficient and $p$-value $(\mathrm{p}<0.05)$ in: capital from bank (corr $=0.116$ ), overdraft (corr $=0.066$ ), lines of credit (corr=0.093), external audit (corr=0.018), capital from suppliers (corr $=0.035)$, and size (corr $=0.052)$. However, the age recorded negative correlation coefficient (corr=-0.024). The correlation coefficients are all significant since their corresponding $p$-values are less than $0.05(\mathrm{p}<0.05)$ in all independent variables.

Table 3. Pairwise correlation between independent variables in access to credit and process innovation

\begin{tabular}{|c|c|c|c|c|c|c|c|c|}
\hline Variables & $\begin{array}{c}\text { Process } \\
\text { Innovation }\end{array}$ & $\begin{array}{l}\text { Capital } \\
\text { from } \\
\text { Bank }\end{array}$ & Overdraft & $\begin{array}{l}\text { Lines } \\
\text { of } \\
\text { Credit }\end{array}$ & $\begin{array}{c}\text { External } \\
\text { Audit }\end{array}$ & $\begin{array}{c}\text { Capital } \\
\text { from } \\
\text { Supplier }\end{array}$ & Age & Size \\
\hline Process Innovation & 1 & & & & & & & \\
\hline Capital from Bank & 0.116 & 1 & & & & & & \\
\hline Overdraft & 0.066 & 0.339 & 1 & & & & & \\
\hline Lines of Credit & 0.093 & 0.473 & 0.39 & 1 & & & & \\
\hline
\end{tabular}




\begin{tabular}{lcccccccc} 
External Audit & 0.018 & 0.167 & 0.246 & 0.194 & 1 & & & \\
Capital from & & & & & & & & \\
Supplier & 0.035 & -0.044 & 0.02 & 0.031 & 0.009 & 1 & & \\
Age & -0.024 & 0.035 & 0.076 & 0.072 & 0.134 & 0.049 & 1 & \\
Size & 0.067 & 0.126 & 0.224 & 0.167 & 0.284 & 0.032 & 0.199 & 1 \\
\hline
\end{tabular}

\subsubsection{Regression model}

The first regression model in this study is created for access to credit and process innovation. The R-squared $\left(R^{2}\right)$ of a regression model explains the extent to which the independent variables are explained by the changes of the dependent variable. This means that for higher $R^{2}$ value, the changes of the independent variables explain more changes in the dependent variable.

The Root mean squared error (RMSE):

$$
\mathrm{RMSE}=\sqrt{\frac{1}{n} \Sigma(\hat{\mathrm{y}}-\mathrm{y})^{2}}
$$

where y: calculated value, and y: expected value,

is a statistical test that estimates how well a model performed. It estimates the relationship that exists between the actual and the expected values. The RMSE in a model shows the root of the sum of square of differences between the actual and the expected values. The goodness-of-fit of a model is greater when the RMSE value is smaller.

The Mean Percentage Error (MPE):

$$
\mathrm{MPE}=\frac{1}{\mathrm{n}} \sum \frac{|\hat{\mathrm{y}}-\mathrm{y}|}{\mathrm{y}}
$$

shows how small or big is the detected error when a regression model is estimated. Small MPE implies that the test results are not far from the accepted values, while big MPE implies that the test results are not close to the accepted values.

\subsubsection{The impact of independent variables in access to credit on process innovation}

Table 4 is the regression analysis of access to credit (working capital from bank, overdraft facility, lines of credit, external audit and working capital from suppliers), control variables (age and size) and dependent variable (process innovation). The regression analysis is performed by the use of the regression model in equation 3 below:

$$
\begin{gathered}
\text { Process_innovation }=\beta_{0}+\beta_{1} \text { Capital_from_bank }+\beta_{2} \text { Overdraft }+\beta_{3} \text { Credit_lines }+ \\
\beta_{4} \text { External_audit_of_account }+\beta_{5} \text { Capital_from_supplier }+\beta_{6} \text { Age }+\beta_{7} \text { Size }
\end{gathered}
$$

For this regression model the total number of firms under consideration is 15,446 . The R-squared of the regression is 0.249 , while the root mean squared error (Root MSE) is 0.422 , and the mean percentage error (MPE) is found as 0.384 .

The impact of working capital from bank, overdraft facility, lines of credit, external audit and working capital from suppliers on process innovation are all statistically significant, with $\mathrm{p}<0.05$.

Table 4. The impact of independent variables in access to credit on process innovation

\begin{tabular}{lccclc}
\hline Source & SS & df & MS & Number of obs. & 15446 \\
& & & & F(48, 15397) & 106.38 \\
Model & 910.336 & 48 & 18.965 & Prob. > F & 0.000 \\
Residual & 2744.882 & 15397 & 0.178 & R-squared & 0.249 \\
& & & & Adj. R-squared & 0.247
\end{tabular}




\begin{tabular}{lcccccc} 
Total & 3655.218 & 15445 & 0.237 & Root MSE & & 0.422 \\
& & & & MPE & & 0.384 \\
\multicolumn{1}{c}{ Variables } & Coefficient & $\begin{array}{c}\text { Standard } \\
\text { Error }\end{array}$ & T-test & P-value & Confidence interval \\
Capital from Bank & 0.001 & $0.2 \mathrm{E}-03$ & 5.23 & 0.001 & 0.001 & 0.002 \\
Overdraft & 0.025 & 0.009 & 2.65 & 0.008 & 0.006 & 0.043 \\
Lines of Credit & 0.055 & 0.011 & 5.06 & $0.4 \mathrm{E}-07$ & 0.033 & 0.076 \\
External Audit & 0.102 & 0.008 & 12.8 & 0.001 & 0.086 & 0.117 \\
Capital from & & & & & & \\
Supplier & $0.4 \mathrm{E}-03$ & 0.000 & 2.67 & 0.008 & $0.1 \mathrm{E}-03$ & 0.001 \\
Age & $-0.7 \mathrm{E}-04$ & $0.1 \mathrm{E}-03$ & -0.29 & 0.771 & -0.001 & $0.4 \mathrm{E}-03$ \\
Size (SME) & 0.002 & $0.2 \mathrm{E}-03$ & 8.08 & 0.001 & 0.001 & 0.002 \\
Constant & 0.006 & 0.04 & 0.15 & 0.877 & -0.072 & 0.084 \\
\hline
\end{tabular}

Note: Country fixed effect - Yes; Industry fixed effect - Yes

The regression coefficients and the $\mathrm{p}$-values for the independent variables in access to credit are: capital from bank $\left(\beta_{1}=0.001, \mathrm{p}=0.001\right)$, overdraft facility $\left(\beta_{2}=0.025, \mathrm{p}=0.008\right)$, lines of credit $\left(\beta_{3}=-0.055, \mathrm{p}=0.4 \mathrm{E}-7\right)$, external audit $\left(\beta_{4}=0.102, \mathrm{p}=0.001\right)$, capital from supplier $\left(\beta_{5}=0.4 \mathrm{E}-3, \mathrm{p}=0.008\right)$, age $\left(\beta_{6}=-0.7 \mathrm{E}-4, \mathrm{p}=0.771\right)$, and size $\left(\beta_{7}=0.002, \mathrm{p}=0.001\right)$.

\subsubsection{Forecasting the impact of access to credit on process innovation}

After using the regression model to estimate the significant impact of the independent variables in access to credit on the dependent variable in process innovation, $Y_{\text {exp }}$, the regression model is used to forecast the values of the dependent variable. Through the function of sumproduct in excel, the regression coefficients are used to estimate the calculated value, $Y_{c}$. A threshold, $\varepsilon$, is then determined to distinguish 0 and 1 from the calculated value in decimals, and it is experimentally predicted to make the forecast error smallest.

Assume that the values of the independent variables in access to credit $\left(x_{1}, x_{2}, x_{3}, x_{4}, x_{5}, x_{6}\right.$, and $\left.x_{7}\right)$ and the dependent variable in process innovation are supplied, and the corresponding regression coefficients are: $\beta_{0}, \beta_{1}, \beta_{2}, \beta_{3}, \beta_{4}, \beta_{5}, \beta_{6}$ and $\beta_{7}$. The OLS regression model is constructed as:

$$
Y_{c}=\beta_{0}+\beta_{1} x_{1}+\beta_{2} x_{2}+\beta_{3} x_{3}+\beta_{4} x_{4}+\beta_{5} x_{5}+\beta_{6} x_{6}+\beta_{7} x_{7}
$$

The calculated values $Y_{c}$ are transformed into dummy variable, $Y_{p}$ :

The error of the forecasting is calculated by:

$$
Y_{p}=\left\{\begin{array}{l}
1, Y_{c} \geq \varepsilon \\
0, Y_{c}<\varepsilon
\end{array}\right.
$$

Accuracy of the forecasting is calculated by:

$$
\text { Error }=\left\{\begin{array}{l}
0, Y_{p}=Y_{\text {exp }} \\
1, Y_{p} \neq Y_{\text {exp }}
\end{array}\right.
$$

$$
\text { Acc. }=1-\frac{\text { EError }}{N}
$$

where $N$ is the number of observations and Acc. is the accuracy of forecasting.

Recall that the prediction value is given by:

$$
Y_{p}=\left\{\begin{array}{l}
1, Y_{c} \geq \varepsilon \\
0, Y_{c}<\varepsilon
\end{array}\right.
$$

Therefore if $Y_{p}=1$, a firm whose data is given is potentially a firm with process innovation while $Y_{p}=0$ implies a firm with potentially no process innovation. 


\subsubsection{Policy proposal}

The firm with independent variable values: $x_{1}, x_{2}, x_{3}, x_{4}, x_{5}, x_{6}$ and $x_{7}$ are moved around the given values and their impacts on $Y_{c}$ are noticed. At a point where $Y_{c}$ is reached to a value $Y_{p} \geq \varepsilon$, the section of these values: $x_{1}, \ldots, x_{7}$ are given to the firm. If the firm is able to enhance the existing values to those values that provide $Y_{c} \geq \varepsilon$, the firm will therefore be considered as having the potential to make process innovation.

The Table 5 below shows how regression model in equation 3 can be used to predict whether a firm is able to achieve process innovation or not. It reveals that when a threshold of $\varepsilon=0.020$ is used the forecast by regression model has the accuracy of $54.30 \%$.

Table 5. Forecasting the impact of access to credit on process innovation

\begin{tabular}{|c|c|c|c|c|c|c|c|c|c|c|c|c|c|c|c|}
\hline N. Prc. Exp. & 0.084 & 0.001 & 0.025 & 0.055 & 0.102 & 0.000 & 0.000 & 0.002 & Cal. Val. N. Prc. Forc.. & Error & Accuracy \\
\hline 1 & 1 & 40 & 1 & 0 & 1 & 0 & 19 & 45 & 0.322 & 1 & 0 & $54.30 \%$ \\
\hline 0 & 1 & 0 & 0 & 0 & 1 & 0 & 1 & 20 & 0.217 & 1 & 1 & 1 \\
\hline 0 & 1 & 0 & 1 & 0 & 1 & 0 & 11 & 50 & 0.287 & 1 & 1 & Threshold \\
\hline 0 & 1 & 80 & 1 & 1 & 1 & 0 & 16 & 52 & 0.432 & 1 & 1 & 0.202 \\
\hline 0 & 1 & 100 & 0 & 0 & 1 & 0 & 33 & 31 & 0.341 & 1 & 1 \\
\hline 0 & 1 & 25 & 1 & 0 & 1 & 0 & 11 & 78 & 0.357 & 1 & 1 \\
\hline 0 & 1 & 15 & 0 & 1 & 0 & 0 & 7 & 43 & 0.221 & 1 & 1 \\
\hline 0 & 1 & 0 & 1 & 1 & 1 & 80 & 44 & 8 & 0.314 & 1 & 1 \\
\hline 1 & 1 & 0 & 0 & 0 & 1 & 0 & 20 & 34 & 0.237 & 1 & 0 \\
\hline 0 & 1 & 0 & 0 & 0 & 0 & 0 & 22 & 20 & 0.113 & 0 & 0 \\
\hline 0 & 1 & 0 & 1 & 0 & 0 & 0 & 26 & 9 & 0.121 & 0 & 0 \\
\hline 1 & 1 & 0 & 0 & 0 & 1 & 100 & 24 & 12 & 0.252 & 1 & 0 \\
\hline
\end{tabular}

\section{Discussion and conclusion}

Discussions of the findings from the regression analyses and the level of forecasting through the regression models are shown in this section. The contributions and implications of the findings from the regression analyses are further explained in this section. Also in this section are the limitations identified in this research and areas for future studies by investigators.

\subsection{Main effects of access to credit on process innovation as seen in the regression model}

The hypotheses claim that the access to credit provides a significant contribution for SMEs to undertake process innovation. The results obtained from the analysis of the regression model in equation 3 reveals that the factors in access to credit have a significant impact on process innovation. In examining the impact of the factors in access to credit on process innovation, for $\mathrm{H} 3 \mathrm{a}$; capital from bank has a positive regression coefficient $\left(\beta_{1}=0.001\right)$, with a standard error of $0.2 \mathrm{E}-3$, and a high statistically significance level with a $\mathrm{p}$ value of 0.001 . At a $95 \%$ level of confidence, confidence interval of the regression coefficient of capital from bank is $(0.001,0.002)$. For $\mathrm{H} 3 \mathrm{~b}$, overdraft has a positive regression coefficient $\left(\beta_{2}=0.025\right)$, with a standard error of 0.009 , and a high statistically significance level ( $\mathrm{p}$-value $=0.008$ ). At a $95 \%$ level of confidence, confidence interval of the regression coefficient of overdraft is $(0.006,0.044)$. For H3c, lines of credit has a positive regression coefficient $\left(\beta_{3}=0.055\right)$, with a standard error of 0.011 , and a high significance level ( $\mathrm{p}$ value $=0.4 \mathrm{E}-7)$. At a $95 \%$ level of confidence, confidence interval of the regression coefficient of lines of credit is $(0.033,0.076)$. For H3d, external audit has a positive regression coefficient $\left(\beta_{4}=0.102\right)$, with a standard error of 0.008 , and a high significance level ( $\mathrm{p}$-value $=0.001)$. At a 95\% level of confidence, confidence interval of the regression coefficient of external audit is $(0.086,0.117)$. For H3e, capital from 
suppliers has a positive regression coefficient $\left(\beta_{5}=0.1 \mathrm{E}-3\right)$, with a standard error of $0.1 \mathrm{E}-3$, and a high significance level ( $p$-value $=0.008$ ). At a 95\% level of confidence, confidence interval of the regression coefficient of capital from suppliers is $(0.1 \mathrm{E}-3,0.001)$.

The regression model in equation 3 shows that with a total number of 15,446 firms observed, the proportion of variation of process innovation that is explained by the independent variables (R-squared) is found as 0.249. The analysis of the regression model reveals that the impact of factors of access to credit on process innovation is significantly high.

\subsubsection{Contributions}

The regression analysis indicates a relatively strong relation between access to credit and process innovation. In the same vein, factors of access to credit are selected to determine their impact on the process innovation. There is a highly significant impact of access to credit on process innovation. This is in line with the works of Giannakas and Fulton (2005); and Bertschek (1995) which reiterate the importance of access to credit to advancement of firms' process innovation [23], [25]. The p-values are capital from a bank $(\mathrm{p}=0.001)$, overdraft $(\mathrm{p}=0.008)$, lines of credit $(\mathrm{p}=0.4 \mathrm{E}-7)$, external audit $(\mathrm{p}=0.001)$ and capital from suppliers $(\mathrm{p}=0.008)$. It can be concluded from the analysis that factors of access to credit significantly impact on the activities of SMEs to achieve process innovation.

\subsubsection{Implications of the findings of the impact of access to credit on innovation}

The findings of this research have both managerial and theoretical implications. This research helps scholars to understand and appreciate the theoretical discussions on innovation management. Managers of firms and SMEs are also guided by the results of this research in their decision making and policy directions.

\subsubsection{Managerial and theoretical implications}

Managers in SMEs who are pursuing process innovation should focus on exploring various means of access to credit for their activities. One of the means is to engage external auditing firms to audit and certify their financial statements. Getting financial assistance from the informal or unregulated sector of the economy has the potential to improve SMEs process innovation. Using the regression model, management is able to predict the outcome of their policy decisions on process innovation given the factors of access to credit available. The accuracy of forecasting from the regression model is shown in equation 3. The findings from the regression analyses support the assertion that audited financial statements contribute positively and significantly to innovations in SMEs. This will for instance, enable SMEs to employ the services of auditors for their growth and development. Secondly, the findings from this research will aid the policy directions of the management of financial institutions to recognise which of the diverse forms of credit, when allocated to SMEs, will have a better impact on their pathway to process innovation.

These credit types that contribute to the growth and development of firms have been on-going discussions in prior literature [29], [10]. The results from this research have given more insight into the appreciation of the discussions and studies on access to diverse forms of credit and innovation in SMEs.

\subsection{Limitations and future research}

The research considers only process innovation in SMEs. Future research can focus on other forms of innovation in the firm, such as: market innovation, product innovation, and organizational innovation. Again, this research is situated in two geographical regions in the world, thus Africa and the Middle East. Future research should consider access to credit by SMEs in other geographic and economic regions such as: East 
Asia and the Pacific, Latin America and the Caribbean, South Asia, and Central Asia to evaluate their impact on innovation.

\section{References}

[1] J. A. Schumpeter, Theory of Economic Developemnt, Cambridge: Harvard University Press, 1934.

[2] J. Sundbo, The Theory of Innovation: Entreprenuers, Technology and Strategy, Cheltenham: Edward Elgar, 1998.

[3] D. C. Galunic and S. Rodan, "Resource Recombination in the Firm: Knowledge Structures and the Potential for Schumpeterian Innovation,” Strategic Management Journal, 19, pp. 1193-1201, 1998.

[4] B. Durakovic and A. Cosic, "Impact of Quality and Innovation Strategies on Busines Performance of Bosnian B2B and B2C Companies," Sustainable Engineering and Innovation, vol. 1, no. 1, pp. 24-42, 2019.

[5] D. Miller, "Entrepreneurship Correlates in Three Types of Firms," Management Sciences, 29, pp. 770$791,1983$.

[6] J. G. Covin and D. P. Slevin, "A Conceptual Model of Entrepreneurship as Firm Behavior," Entrepreneurship Theory and Practice, 16, pp. 7-25, 1991.

[7] M. A. Hitt, R. E. Hoskisson, R. A. Johnson and D. D. Moesel, "The Market for Corporate Control and Firm Innovation,” Academy of Management Journal, vol. 39, no. 5, pp. 1084-1119, 1996.

[8] D. Dougherty and C. Hardy, "Sustained Product Innovation in Large, Mature Organizations: Overcoming Innovation-to-organization Problems," Academy of Management Journal, 39, pp. 11201153, 1996.

[9] S. A. Zahra, "Governance, Ownership and Corporate Entrepreneurship: The Moderating Impact of Industry Technological Opportunities,” Academy of Management Journal, 39(6), pp. 1713-1735, 1996.

[10] M. Ayyagari, A. Demirguc-Kunt and V. Maksimovic, "Firm Innovation in Emerging Markets: The Role of Finance, Governance, and Competition," The Journal of Financial and Quantitative Analysis, 46(6), pp. 1545-1580, 2011.

[11] H. L. Lin and E. S. Lin, "FDI, Trade and Product Innovatio: Theory and Evidence," Southern Economic Journal, 77(2), pp. 434-464, 2010.

[12] S. Girma, Y. Gong and H. Gorg, "Foreign Direct Investment, Access to Finance and Innovation Activity in Chinese," The World Bank Economic Review, 22(2), pp. 367-382, 2008.

[13] R. Levine, "Finance and Growth: Theory and Evidence," in Handbook of Economic Growth, Amsterdam, Elsevier Science, 2005.

[14] D. S. Evans and B. Jovanovic, "An Estimated Model of Entrepreneurial Choice under Liquidity Constraints," Journal of Political Economy, 97(4), pp. 808-827, 1989.

[15] T. Beck, A. Demirguc-Kunt and V. Maksimovic, "Financing Patterns around the World: Are Small Firms Different?," Journal of Financial Economics, 89(3), pp. 467-487, 2008.

[16] L. Klapper, L. Laeven and A. B. Rajan, "Barriers to Entrepreneurship," Journal of Financial Economics, 82(3), pp. 613-641, 2006.

[17] S. Myers and N. Majluf, "Financing Decisions When Firms Have Information that Investors Do Not Have," Journal of Financial Economics, 13, pp. 187-221, 1984.

[18] L. Bulan and Z. Yan, "The Pecking Order of Financing in the Firm's Life Cycle," Banking and 
Financing Letters, 1(3), pp. 129-140, 2009.

[19] R. A. Brealey and S. C. Myers, Financing and Risk Management, New York: McGraw- Hill, 2003.

[20] R. E. Carpenter and L. Rondi, "Italian Corporate Governance, Investment and Finance," Emperica, 27(4), pp. 365-388, 2000.

[21] S. Shirai, "Banks' Lending Behavior and Firms' Corporate Financing Patterns in People's Republic of China," ADB Institute Research Paper, 43, pp. 1-51, 2002.

[22] E. Muller and V. Zimmermann, "The Importance of Equity Finance for R\&D," Small Business Economics, 33(3), pp. 303-318, 2009.

[23] K. Giannakas and M. Fulton, "Process Innovation Activity in a Mixed Oligopoly: The Role of Cooperatives,” American Journal of Agricultural Economics, 87(2), pp. 406-422, 2005.

[24] J. R. Baldwin, G. Gellatly and V. Gaudreault, "Financing Innovation in New Small Firms: New Evidence from Canada," Statistics Canada Analytical Studies Series, Working Paper No. 190, 2002.

[25] I. Bertschek, "Product and Process Innovation as a Response to Increasing Imprts and Foreign Direct Investment," The Journal Industrial Economics, 43(4), pp. 341-357, 1995.

[26] F. Allen, R. Chakrabarti, S. De, J. Qian and M. Qian, "Financing Firms in India," World Bank Policy Research, Working Paper No. 3975, Washington, D.C, 2006.

[27] S. Djankov, I. Lieberman, J. Mukherjee and T. Nenova, "Going Informal: Benefits and Costs," in The Informal Economy in the EU Accession Countries, Sofia, Center for the Study of Democracy, 2002, pp. 63-80.

[28] S. Mehnaz and J. Wimpey, "When do Enterprises Prefer Informal Credit?," Policy Research Working Papers, 2008.

[29] M. Ayyagari, A. Demirguc-Kunt and V. Maksimovic, "Formal versus Informal Finance: Evidence from China," Review of Financial Studies, 23(8), pp. 3048-3097, 2010.

[30] Z. Y. Du, "A Literature Review on Institutional Environment and Technological Innovation," America Journal of Industrial and Business Management, vol. 8, pp. 1914-1950, 2018.

[31] R. Levine, N. Loayza and T. Beck, "Financial Intermediation and Growth: Causality and Causes," Journal of Monetary Economics, 46, pp. 31-77, 2000.

[32] R. G. Rajan and L. Zingales, "Financial Dependence and Growth," American Economic Review, 88, pp. 559-586, 1998.

[33] R. S. Chirinko and H. Schaller, "Why Does Liquidity Matter in Investment Equations?," Journal of Money, Credit and Banking, 27(2), pp. 527-548, 1995.

[34] H. Schaller, "Asymmetric Information, Liquidity Constraints and Canadian Investment," Canadian Journal of Economics, 26(3), pp. 552-574, 1993.

[35] T. Hoshi, A. Kashyap and D. Scharfstein, "Corporate Structure, Liquidity and Investment: Evidence from Japanese Industrial Groups,” Quarterly Journal of Economics, 106(1), pp. 33-60, 1991.

[36] M. J. K. Thavaraj, “The Overdraft Problem in Perspective," Social Scientist, 10(10), pp. 3-10, 1982.

[37] D. S. Landes, The Unbound Prometheus: Technological Change and Industrial Development in Western Europe from 1750 to the Present, Cambridge: Cambridge University Press, 1969.

[38] N. Rosenberg, Inside the Black Box: Technology and Economics, Cambridge: Cambridge University Press, 1982.

[39] J. Mokyr, The Lever of Riches: Technological Creativity and Economic Progress, Oxford University Press, 1990.

[40] R. M. Solow, "Technical Change and the Aggregate Production Function," Review of Economics and 
Statistics, 39, pp. 312-320, 1957.

[41] W. Bonte and S. Nielen, "Production Innovation, Credit Constraints and Trade Credit: Evidence from a Cross-country Study,” Managerial and Decision Economics, 32(6), pp. 413-424, 2011.

[42] C. K. Ng, J. K. Smith and R. L. Smith, "Evidence on the Determinants of Credit Terms Used in Interfirm Trade," Journal of Finance, 54(3), pp. 1109-1129, 1999.

[43] D. Tsuruta, "Bank Information Monopoly and Trade Credit: Do only Banks Have Information about Small Businesses?," Applied Economics, 40(8), pp. 981-996, 2008.

[44] V. Cunat, "Trade Credit: Suppliers as Debt Collectors and Insurance Providers," Review of Financial Studies, vol. 20, no. 2, pp. 491-527, 2007.

[45] C. Howorth and B. Reber, "Habitual Late Payment Trade Credit: An Empirical Examination of UK Small Firms," Managerial and Decision Economics, 24, pp. 471-482, 2003.

[46] L. Guiso, "High-tech Firms and Credit Rationing," Journal of Economic Behavior \& Organization, 35, pp. 39-59, 1998.

[47] A. Hyytinen and O. Toivanen, "Do Financial Constraints Hold Back Innovation and Growht? Evidence on the Role of Public Policy," Research Policy, 34, pp. 1385-1403, 2005.

[48] E. Ughetto, "Industrial Districts and Financial Constraints to Innovation," International Review of Applied Economics, 23, pp. 597-624, 2009.

[49] F. Jaramillo, F. Schiantarelli and A. Weiss, "Capital Market Imperfections before and after Financial Liberalization: An Euler Equation Approach to Panel Data for Ecuadorian Firms," Journal of Development Economics, 51, pp. 367-386, 1996.

[50] T. Beck, A. Demirguc-Kunt and V. Maksimovic, "Financial and Legal Constraints to Firm Growth: Does Firm Size Matter?," Journal of Finance, 60(1), pp. 137-177, 2005.

[51] P. Aghion, T. Fally and S. Scarpetta, "Credit Constraints as a Barrier to the Entry and Post-entry Growth of Firms," Economic Policy, vol. 22, no. 52, pp. 732-779, 2007.

[52] R. Pike, N. S. Cheng, K. Carvens and D. Lamminmaki, "Trade Credit Terms: Asymmetric Information and Price Discrimination Evidence from Three Continents," Journal of Business Finance \& Accounting, 32(5\&6), pp. 1197-1236, 2005.

[53] M. A. Petersen and R. G. Rajan, "The Benefits of Lending Relationships: Evidence from Small Business Data," Journal of Finance, 49(1), pp. 3-37, 1994.

[54] R. A. Schwartz, "An Economic Model of Trade and Credit," Journal of Financial and Quantitative Analysis, 9, pp. 643-657, 1974.

[55] R. Bastos and J. Pindado, "An Agency Model to Explain Trade Credit Policy and Empirical Evidence," Applied Economics, 39, pp. 2631-2642, 2007.

[56] M. Minnis, "The Value of Financial Statement Verification in Debt Financing: Evidence from Private U.S. Firms," Journal of Accounting Research, 49(2), pp. 457-506, 2011.

[57] J. Sinkey, Commercial Bank Financial Management (6th Ed), Upper Saddle River: Prentice Hall, 2002.

[58] L. Maines and J. Wahlen, "The Nature of Accounting Information Reliability: Inferences from Archival and Experimental Research," Accounting Horizons, 20, pp. 399-425, 2006.

[59] J. Tidd, J. Bessant and K. Pavitt, Managing Innovation: Integrating Technological, Market and Organizational Change (3rd ed), West Sussex: John Wiley \& Sons Ltd, 2005.

[60] J. J. Wetter, The Impact of Research and Development Expenditures: The Relationship between Total Factor Productivity and U.S. Gross Domestic Product Performance, New York: Springer, 2011.

[61] OECD, Oslo Manual: Guidelines for Collecting and Interpreting Technology Innovation Data (3rd Ed), 
Paris: OECD Publishing, 2005.

[62] A. Cabagnols and C. L. Bas, "Differences in the Determinants of Product and Process Innovations: The Franch Case," in Innovation and Firm Performance. Econometric Explorations of Survey Data, Basingstoke, UK, Palgrave, 2002.

[63] R. G. M. Kemp, M. Folkeringa, J. P. J. de Jong and E. F. M. Wubben, "Innovation and Firm Performance,” Scientific Analysis of Entrepreneurship and SMEs, p. Research Report H200207, 2003.

[64] J. Fagerberg, D. C. Mowery and R. Nelson, The Oxford Handbook of Innovation, Oxford: Oxford University Press, 2004.

[65] The World Bank, "Full Survey Data," 2018. [Online]. Available: https://www.enterprisesurveys.org/portal/login.aspx.

[66] J. S. Yang, "The Governance Environment and Innovative SMEs," The World Bank, November 8, pp. 127, 2016.

[67] J. A. LiPuma, S. L. Newbert and J. P. Doh, "The Effects of Institutional Quality on Firm Export Performance in Emerging Economies: A Contingency Model of Firm Age and Size," Small Business Economics, 40, pp. 817-841, 2011. 